\title{
EMPIRICAL INVESTIGATION OF DETERMINANT FACTORS OF COMPANY DELISTING: EVIDENCE FROM INDONESIA
}

\author{
Leslie Benny ${ }^{1}$ \\ BINUS University International \\ Yanthi Hutagaol ${ }^{2}$ \\ BINUS University International
}

\begin{abstract}
The main purpose of the research is to evaluate determinant factors which contribute to companies being delisted from Stock Exchange Market in Indonesia. The samples are taken from the delisted companies list in IDX for a period year 2007-2011. The matching companies are then selected based on the company size to make an equivalent comparison for each delisted companies sample. The total final samples consist of 58 companies, 29 delisted companies and 29 matching companies. This research analyzes the company's financial status by using descriptive statistics, independent sample t-test, and logistic regression model to find the effect of each determinant to the probability of delisting. The shares liquidity is a significant determinant to company's delisting in Indonesia. Meanwhile, profitability and leverage seems to be determinant factors for delisted, but appear to be insignificant. Other examined factors, market capitalization and growth opportunity appear to insignificant determinants. This manager implication of this research is that the strong delisting factor is the external company factor, in this case, the market factor,
\end{abstract}

Keywords: delisting, determinants, liquidity, logistic regression, IDX.

1 Alumni School of Accounting, BINUS University International

(blue_rhapsody@yahoo.com).

2 Faculty of Business, BINUS University International (yhutagaol@binus.edu). 


\section{INTRODUCTION}

\section{Background}

One of many corporate financial issues that affect the listed company in regional stock exchange is delisting. Delisting itself is defined as the removal of listed company's stock from the stock exchange market on which it trades (Siddaiah, 2011).

In Indonesia, delisting is quite a new issue in corporate finance research. The phenomena of the delisting in Indonesia started to immerse in 1996, when PT Praxair Indonesia Tbk were announced delisted. Then, in 2002, three listed companies (PT Pfizer Indonesia Tbk., PT Miwon Indonesia Tbk., PT Indocopper Investama Tbk) were delisted in 2002 (Hernawan, 2005). The IDX statistic shows that at least 10 companies have been delisted from Indonesia Stock Exchanges ince 2009 (IDX, 2012).

In 2011, Indonesia Stock Exchange delisted 5 public companies (IDX, 2011). "This year delisting events are not the record because more delisting events are occurred in 2009. Delisting is caused by go private companies, such as AQUA and Alfa Retailindo and Dynaplast. This is unavoidable due to globalization," as stated by Ito Warsito, as Chief Director of Indonesia Stock Exchange, in the last press conference in 2011 at Indonesia Stock Exchange building, Jakarta, December $30^{\text {th }}$ (Seputar Indonesia, 2011).

Table 1. Number of Delisted Companies in Indonesia Stock Exchange in 2007-2011

\begin{tabular}{llllll}
\hline $\mathbf{2 0 0 7}$ & $\mathbf{2 0 0 8}$ & $\mathbf{2 0 0 9}$ & $\mathbf{2 0 1 0}$ & $\mathbf{2 0 1 1}$ & Total \\
\hline 8 & 6 & 11 & 1 & 5 & 31 \\
\hline
\end{tabular}

Source: www.idx.co.id

The delisting can be distinguished into two types, which are forced/compulsory delisting and voluntary delisting (Siddaiah, 2011). Some of the shareholders may be willing to choose to delist the company they invest in, this is known as voluntary delisting, where the delisting is done by the approval of General Meeting of the Shareholders; this voluntary delisting is referred to as a "Going 
Private Transaction" (GPT) (Djama et al., 2012).Research stated that in 1993-1994; approximately 70 public companies which are listed in stock exchange market in United States became "go-private" companies (Hernawan and Tirtayatra, 2005). While in the forced delisting context, a firm gets delisted because it experiences financial distress or has been merged and/or acquired by another firm (Djama et al., 2012).

Staging Connections Group Limited (ASX: STG) is one example of company's voluntary delisting. The company through its Letter of ASX Announcement announced that it has realized a buy-back of ordinary shares for shareholders that hold less than marketable parcel of shares in order to reduce the costs associated with the unmarketable parcels (Staging Connections Group Limited (ASX: STG): ASX Announcement, 2011). On the other hand, Automated Touchstone Machine Limited, a case of forced delisting, was delisted from Singapore Stock Exchange in September 2008 due to internal control failure, which is caused by internal audit issue (Loon and Pica, 2010). In the most extreme cases, parent companies could take assets from its listed subsidiary after subsidiary's value added from the Initial Public Offering, like it happened to the first-ever forced delisting case, or even first-ever delisting case in China by ST Monkey King Company (Loon and De Ramos, 2009). These cases are several examples of delisting events which are happened worldwide.

There are some more reasons why company is delisted, for both voluntary and forced delisting. To the authors' knowledge there is no study has been undertaken to examine the internal and market factors that cause the companies being delisted in Indonesia market. Therefore, this paper aims to identify the determinant factors of delisting which occurred in the stock exchange market in Indonesia, and the characteristics of a company which has the possibility of being delistedin IDX (Indonesia Stock Exchange).

\section{THEORETICAL FOUNDATION}




\section{Delisitng}

Decision of Board of Directors of The Jakarta Stock Exchange (2004), concerning Delisting and Relisting of Securities at the Exchange, define delisting as follows:

"PenghapusanPencatatan (Delisting)means the delisting of Securities from the Securities list listed at the Exchange, consequently they cannot be traded at the Exchange."

Mantysaari (2009), as well as Black (1990), defines delisting as the termination of the securities which formerly admitted to trading on a certain market. In addition, Siddaiah (2011) also stated delisting of securities as permanent removal of securities of a listed company from a stock exchange. The public company whose shares are being delisted will turn to a privately held company; this is implied as delisting, although the delisted company may continue to be a public limited company. He then stated that a delisted security will make the investors to lose the opportunity to exchange these securities.

\section{- Classifications of Delisting}

Siddaiah (2011) and Das, et al. (2004) categorized delisting into two forms, which are voluntary delisting and involuntary/compulsory delisting.

The company itself may delist its shares from stock exchange where it is listed by achieving at least 75 percent approval in General Shareholder's Meeting for the resolution of delisting decision. One example of company's voluntary delisting si Staging Connections Group Limited (ASX: STG). The company through its Letter of ASX Announcement declared that it has executed a buy-back of common shares for shareholders that hold less than marketable parcel of shares in order to reduce the costs associated with the unmarketable parcels. Through its Annual General Meeting, the Board has decided to put a resolution to shareholders to seek removal Company's securities from quotation on Australia Stock Exchange, after carefully considering several alternatives (Staging Connections Group Limited (ASX: STG): ASX Announcement, 2011).

In contrast, Das (2004) and Chaplinsky, et al. (2006) as well as Siddaiah (2011) stated that, in compulsory/involuntary delisting, the securities of listed company is compulsorily/forcefully removed by the stock exchange itself under certain procedures since the company 
is unable to fulfill the stock exchange's regulatory standards; most often cases due to poor performance. The required procedures for listing standards are, for example, required net income, required number of shareholders, required market capitalization, etc (Das, 2004).

\section{- The Delisting Process}

The delisting process, stated by Board of Directors of The Jakarta Stock Exchange Inc. (2004) and Mantysaari (2009), can be differed between delisting of shares by request of the Listed Company and delisting of shares by the Exchange.

Widjaja (2009) and Macey et al. (2003) stated that in New York Stock Exchange (NYSE), Exchange Committee will only delist shares by company's request, if company sufficiently fulfilled certain circumstances of delisting criteria. Before the delisting is completed, NYSE will give a notification through written report to the company, which must then issue a press release. The company may request to review the decision to the Committee of the Board of Directors of the Exchange, within ten days after receiving the notification. The company then will give briefs and oral arguments to the Committee about the delisting. The request for review usually stays the delisting proceedings. During the review, the Exchange may suspend the security trading, even though delisting is not yet finalized. Finally, if the review is failed to be accomplished, the Exchange will discontinue the trading and apply to remove the security from listing to the Securities and Exchange Commission (SEC). Similar procedure of delisting by company's request could be found in Indonesia Stock Exchange (IDX) and Nasdaq.

Meanwhile, the procedure of delisting of shares by the Exchange, based on Decision of Board of Directors of the Jakarta Stock Exchange Inc.Number: Kep-308/BEJ/07-2004, concerning Delisting and Relisting of Securities at the Exchange, are as follows:

1. If there is an indication that Listed Company experiences one or more conditions stated in the listing requirements, then the Exchange shall conduct a Hearing with the Listed Company.

2. If the Exchange decides to do the delisting, the Exchange shall make a notification regarding the decision of the relevant Listed Company delisting and the delisting schedule on the same 
exchange day as the decision of the delisting of shares with a copy to Bapepam.

3. The Exchange will then declare at the Exchange regarding delisting decision of the Listed Company as well as the delisting schedule of the relevant Listed Company. Announcement will be conducted, at the latest, in the beginning of session I next exchange day after the delisting decision by the Exchange.

4. If necessary, the Exchange may suspend the delisted share for 5 Exchange days and will further trade the shares only at Negotiable Market for 20 Exchange days prior to the effective date of the Delisting.

5. The delisting shall be effective on the date agreed by the Exchange in the Delisting decision, and shall be announced at the Exchange.

\section{- The Advantages and Disadvantages of Delisting}

Delisting activity is mostly related to negative effects, but it also benefits the company for some reasons:

1. Listing Costs Termination

Djama, et al (2012), as well as Leuz (2004), Marosi and Massoud (2005), divided the costs of stock exchange listing into direct costs and indirect costs. Direct costs contain the fixed costs following IPOs, such as registration cost and underwriting fees, covering annual listing fees imposed by the stock exchange regulation and trading costs. While indirect costs are mainly related to the responsibility of company's top level management (executives, directors and board) in publicly information production costs (i.e., publication costs related to disclosure and audit costs), as well as compliance costs to meet regulatory and corporate governance standards, and opportunity costs.

For some firms, the costs of maintaining a listing outweigh the benefits (Mantysaari, 2009). By delisting its stock in the stock exchange market, companies are no longer required to pay such fees; therefore they can minimize the costs incurred, especially for small companies which have infrequently traded stocks.

\section{Flexibility and Private Benefits}

Flexibility, based on Parker (2004), means when a firm is private and relatively closely held, several sections of corporate governance can be conducted informally. Unlike publicly listed companies, private 
companies may conduct flexible management system without afraid of being suspended by the regulation (Widjaja and Risnamanitis, 2009), for example general shareholders meeting may or may not actually be held on an annual basis (Parker, 2004). Private equity investors are likely attracted to less-monitored firms (private companies) because of higher potential for value creation/flexibility (Djama et al., 2012).

\section{Long-Term Focus}

Public companies, as stated by Parker (2004), are often forced to focus on quarterly results, in contrast to long-term goals and strategies. Moreover, he stated that public companies are frequently encountered with the dilemma of suspending promising long-term projects that may have a negative impact on short-term (quarterly) results. Thus, through delisting, company permits its management to focus on long-term goals, rather than to satisfy next short-term earnings (Parker, 2004; Public Company Considerations for Going Private, 2012).

On the other hand, beside of some advantages stated above, the negative effects should also be considered. Widjaja and Risnamanitis (2009) stated some consequences, from the perspective of company as issuer, investors, and its securities, will occur if a publicly held company turn to private company. Some negative effects/disadvantages that may be caused by company's delisting are as follows:

1. Effect to Company as Issuer

The main purpose of why company issue stock publicly through stock exchange market is to raise capital more rapidly and effectively for the sake of its growth rather than borrowing from financial institutions, e.g. bank. Moreover, a listed company receives more privileges, for example, it will be easier to loan on long-term debt for a listed company rather than a private company, because of the trust of company's credibility (Widjaja et al., 2009). Through delisting, company is no longer getting such privilege. Sanger (1990), as well as Chandy, et al. (2004), also supported negative effect of delisting to the company which decreases the value of the firm by diminishing its liquidity.

2. Effect to Company's Share 
The most immediate effect of delisting announcement is on its share price (Macey et al., 2003). A research done by Macey, O'Hara and Pompilio (2003) shows a significant dropping price of share, at approximately half of the price, after delisting announcement (on the last day of NYSE trading, the average stock in the sample closed at a price of $\$ 0.95$, but on the first day post-delisting, the average stock closed at $\$ 0.48$; similarly occurred for large stocks which drops from 0.63 to 0.28 after delisting). These effects suggest both that the delisting event was not anticipated by the market, and that it is a traumatic event for the stock and its investors.

In addition, You et al. (2009) identified that delisting also caused the changes in trading volume. They then stated, through their research, that the delisting event forces the trading volume to be steadily declined and fell back to a level that is even lower than the trading volume ten years before the delisting. By interpreting the trading volume as a liquidity measurement, they also concluded that the delisting reduces liquidity on the long-run effect.

\section{Effect to Investors}

Investors are, of course, seeking to receive high capital gain from company's shares which they invested in. But, what investors must consider is investment in capital market is like a two-sided knife; they could multiply their wealth or lose all their investment.

"The investors will lose the opportunity to trade in these securities. In other words, consequent to delisting of securities, the investors will lose liquidity of their holdings. In such a case, the investors may not have any exit route." (Siddaiah, 2011)

Through company's delisting, a worst case scenario which investors might face is a very large costs, with a falling of share prices which approximately half of the price (Macey et al., 2003). And again, the delisting event could be such a traumatic event for the investors of capital market.

\section{Determinant Factors of Company Delisting \\ - Profitability}

Profitability of a firm is also a significant determinant factor of company's survivorship. Chaplinsky and Ramchand (2006) identified that one of the important determinants for firm's survival in the U.S. market is profitability. They found that firms voluntarily delisting 
following passage of Sarbanes-Oxley have low average of profitability, median assets and market capitalization less than $\$ 230$ million. By using the ROA as a measurement of profitability, Chaplinsky and Ramchand (2006) observed over the results of entire sample period, 1961-2004, that at the time of listing, the delisted firms have lower profitability in comparison to the stay listed firms. Moreover, they stated that both voluntary and involuntary delists have negative ROA on average, compared to New Lists. Their research then draw in a conclusion which is stated that larger, more profitable firms, with proportionally more U.S. trading volume, and the ability to raise capital are more likely to survive in the U.S. market, or in other words more invulnerable from delisting. Sanger (1990) stated that most delisting events result from a failure to meet numerical standards; one of them which are related to profitability is minimum net income. Negative abnormal returns also found in a sample of 17 delisted firms by Edelman and Baker (1987). Later, Edelman and Baker $(1990,1992)$ concluded that while delisting may decrease the value of a firm by diminishing its liquidity, consistent with a rational market response to the negative performance that usually leads to delisting.

\section{- Share's Liquidity}

Mehran and Pestriani (2009) stated that the main factor behind the decision to go private is liquidity of company's stock/share. Chandy, Sarkar and Tripathy (2004), through their research, concluded that a stock's liquidity, market value and cost of capital could be adversely affected by delisting occurred from the National Market System (NMS); however, rather than be the effect of removal, these adverse conditions could also be a cause of a firm's delisting from NMS. Angel et al. (2004), as well as You, Parhizgari, and Srivastava (2009), using volume of stock's trading as a measurement of liquidity. Angel et al. (2004) investigated a sample of 1098 delisted firms from NASDAQ between 1999 through 2002 and considered a period of three months before and after the involuntary delisting date and found out that involuntary delisting is related to a large decline in liquidity, which is a decline of approximately two-thirds of the trading volume. In conclusion, Chaplinsky and Ramchand (2006), Mehran and Peristiani (2009), Djama, Martinez and Serve (2012), You, Parhizgari, and Srivastava (2009), as well as Leuz, Triantis and Wang (2004), 
agreed that trading volume is significant determinant of firm's delisting from the market.

\section{- Market Capitalization (Share Price)}

Gibson (2011), through his book Financial Statement Analysis, define market capitalization as follows:

"Market capitalization is total value of an entity's outstanding shares at a point in time which reflects the value investors place on a company. It is computed by multiplying the number of common shares outstanding by the share price."

In order to find the relationship between market capitalization and delisting event, several literatures have been found to support the idea. Firstly, Seguin and Smoller (1997) found that based on a sample of 5896 delisted firms from 1974 to 1988, market capitalization and stock price become two primary determinants for the firm's mortality. Macey, O'Hara, and Pompilio (2003), Li, Zhang and Zhou (2006), along with Djama, Martinez and Serve (2012) stated that exchange, such as NYSE, sets out numerical requirement standards for firms to remain listed in which exchange the firms are listed in. One of the standards is the minimum market capitalization. Failing to meet the minimum market capitalization will caused the firm to get delisted by the exchange (Macey et al., 2003). Using share price as a proxy of market capitalization, some relevant literatures have been found. The share price, as a vital measurement of market capitalization, has played an important role in delisting event of a firm. Supporting previous idea, Seguin and Smoller (1997) discovered that the probability of firm's removal is higher for the stocks with lower prices. The management of a firm may decide to go private when they found the share price is undervalued; the decision due to strategic reasons, which are to extract private benefits and to avoid the opportunity costs of staying listed (Kim and Lyn, 1991). Whereas, a fall in stock price could also lead to involuntary delisting (Djama et al., 2012), which consequently affected to the investors' wealth adversely (Baker and Kennedy, 2002).

\section{- Firm's Leverage}

Leverage, also known as borrowing capacity ratio, as defined by Gibson (2011), measures the degree of protection of supplier of longterm funds. Gibson (2011) then distinguished leverage into operating 
leverage and financial leverage. Operating leverage is defined as the existence of operating costs which affects earnings, while financial leverage is the use of debt which has a significant impact to the earnings. Several studies found the significance between firm's leverage and the delisting events. Palepu (1987), Healy and Palepu (1990), DeAngelo, DeAngelo, and Skinner (1996), Leuz, Triantis and Wang (2004), Marosi and Massoud (2005), Li, Zhang, Zou (2006), Thomsen and Vinten (2007), Chemla et al. (2008), Harris (2009), Hansen et al. (2009), Chen (2010) and Djama, Martinez and Serve (2012), found that leverage is a significant characteristic that appeared to be driving factor of delisting. Li, Zhang, and Zou (2006), through their studies with a sample of 3898 IPOs issues in the period of 19801999 that recorded in Securities Data Corporation (SDC) New Issues database, investigated that the failed firms show higher risk in financial leverage; riskier firms are more likely to fail/delist. Similar ideas stated that highly leverage firms are more likely to delist also documented by Palepu (1987), Healy and Palepu (1990), DeAngelo, DeAngelo, and Skinner (1996), Leuz, Triantis and Wang (2004), Marosi and Massoud (2005). Consistent with the findings in prior studies, Chen et al. (2010) found a positive relationship of leverage and delisting probability since higher leverage would increase default risk, leading to more delistings; this idea also supported by Marosi and Massoud (2005) which, through their research of a sample of 406 deregistering firms in the SEC's EDGAR database for January 1996May 2004 period, found that a 1\% increases in leverage increases the probability of delisting increase by $31 \%$.

\section{- Firm's Growth Opportunity}

Kim and Lyn (1991), Fama and French (2004), Marosi and Massoud (2005), Weir et al. (2005), Li, Zhang and Zou (2006), Leuz et al. (2008), Bharath and Dittmar (2010), Martinez and Serve (2011), agreed that delisting also triggered by the firm's growth. Weir et al. (2005) made his investigation from 1998 to 2001 about the incentives of delisting decision by comparing the characteristics of 117 Leverage Buy-Out (LBO) firms with those of a random sample of 362 public companies. He discovered that the delisted firms had lower growth opportunities, as measured by Q ratio, compared to the public firms. $\mathrm{Li}$, Zhang and Zou (2006) also concluded that one controlling variables that related significantly to delisting rates of IPOs is the growth of the firms; the higher the growth of the firms' value the 
higher the probability for the firms to survive after IPO, which also supported by Marosi and Massoud (2005). Thomsen and Vinten (2007) noted that highly valued companies have better growth opportunities and may therefore find it profitable to remain listed to finance further expansion. The authors then described further that low-growth firms will benefit less from being listed, therefore they choose to delist from the exchange to reduce the cost of being listed. Leuz et al. (2008) also confirmed this idea through their research about the impact of SOX (Sarbanes-Oxley Act) on the deregistration decision with a sample of 480 delisted firms in the period between 1998 and 2004. The authors found that smaller firms with poor performance and growth opportunities, for which the compliance cost are particularly burdensome, are more likely to delist.

\section{Hypothesis Development}

This subchapter describes the essential hypotheseswhich are relevant to delisting events which occurred in Indonesia Stock Exchange. Some determinant factors of delisting, which are stated in the theoretical framework above, are not included in the hypotheses due to difficulties in obtaining the data. Therefore, to make the research feasible and reliable, the author considered some determinants which are significant to be included in the development of hypotheses. By considering several literatures, and to conclude this research, five hypotheses are presented. The discussion for the development of each hypothesis is explained as follows:

First Hypothesis:

Chaplinsky and Ramchand (2006) studied and observed the listings and delistings of foreign firms from major U.S. exchanges over the period of approximately 40 years, from 1961-2004; they found that the delisted firms have lower profitability if compared to the listed firms. Edelman and Baker $(1990$, 1992) stated thatnegative performance of the firm usually leads to delisting, consistent with a rational market response. Those researches drew a same concluding idea that the lower the profitability of the firm, the more likely the firm delist from the exchange. This conclusion then drives to the elaboration of first hypothesis, which is:

$H_{1}$ : Profitability of the firm decreases delisting probability

Second Hypothesis: 
Based on the conclusion of their research, Chandy, Sarkar and Tripathy (2004) established that a stock's liquidity, as well as market value and cost of capital, could be a cause of firms' removal in the National Market System (NMS), even though sometimes these variables also can act as the effect of the firms' removal from stock exchange. In short, Chandy et al. (2004) stated that stock's liquidity could act as both cause and effect of delisting of a firm. To support this idea, found from different literature, Angel et al. (2004) found that delisting is related to a large decline in liquidity, which is a decline of approximately two-thirds of the trading volume by studied a sample of 1098 delisted firms from NASDAQ between 1999 through 2002 and considered a period of three months before and after the delisting date. Hence, from several supporting literatures, the second hypothesis is:

probability

$\mathrm{H}_{2}$ : Share's liquidity of the firm decreases delisting

Third Hypothesis:

Macey et al. (2003) stated that one standard requirement for listing procedure is having a minimum market capitalization standard. The share price, as a vital measurement of market capitalization, has been a significant determinant in delisting event of a firm; the lower the price of share the higher the probability of the delisting of the firm (Seguin and Smoller, 1997). Kim and Lyn (1991) documented that due to strategic reasons, when the management of the firm found that the share price is undervalued, they may decide to go private, on in other words getting delist from the stock exchange. This idea also supported by Djama et al. (2012) which stated that a fall in stock price could also lead to involuntary delisting. Based on those philosophies, the third hypothesis is summarized as follows:

$\mathrm{H}_{3}$ : Market capitalization of the firm decreases delisting probability

Fourth Hypothesis:

Palepu (1987), Healy and Palepu (1990), DeAngelo, DeAngelo, and Skinner (1996), Leuz, Triantis and Wang (2004), Marosi and Massoud (2005), Li, Zhang, and Zou (2006), and Chen et al. (2010) agreed that highly leverage firms are more likely to delist. Marosi and Massoud (2005), from their research of a sample of 406 deregistering firms in the SEC's EDGAR database for January 1996-May 2004 
period, found that a $1 \%$ increase in leverage increases the probability of delisting increase by $31 \%$. Li, Zang, Zhou (2006) studied a sample of 3898 IPOs issues in the period of approximately 2 decades (between 1980 and 1999) that recorded in Securities Data Corporation (SDC) New Issues database and investigated that riskier firms which have higher financial leverage are more likely to fail/delist. Additionally, a positive relationship of leverage and delisting probability has also been documented by Chen et al. (2010), since higher leverage would increase default risk which leading to higher delisting probability. To support the goal of this thesis, based on literatures and research done by the author, hence, the fourth hypothesis is proposed as follows:

$\mathrm{H}_{4}$ : Firm's leverage increases delisting probability

\section{Fifth Hypothesis:}

Weir et al. (2005) suggested that the delisted firms had lower growth opportunities compared to the listed public firms. Marosi and Massoud (2005), as well as Li, Zhang and Zou (2006), also concluded that the higher the growth of the firms' value the higher the probability for the firms to survive from delisting. Moreover, higher value firms, which have better growth opportunities, may find it an advantage to remain listed for their further expansion, while the lower-growth firms will choose to delist from exchange because they benefit less from being listed and to reduce the listing costs (Thomsen and Vinten, 2007). This idea also confirmed by Leuz et al. (2008) by a conclusion that smaller firms with poor performance and growth opportunities are more likely to delist. By supporting the literature, this thesis would like to test the last hypothesis which is as follows:

$\mathrm{H}_{5}$ : Firm's Growth Opportunity decreases delisting probability

\section{RESEARCH METHOD}

\section{Sampling Design}

This thesis utilizes nonprobability sampling, in which the elements in the population, in this case are the delisted firms in IDX, do not have a known or predetermined chance probability of being selected as a sample subjects (Sekaran and Bougie, 2010). The sample of the firms is selected based on the firms which is delisted from Indonesia Stock 
Exchange for a period of 2007-2011, which are 31 firms. To differentiate the probability of delisting, a matching firm is selected to accompany each delisted firms.

The matching firm criteria are as follows:

1. Firms have stocks which are actively traded firm in Indonesia Stock Exchange.

2. Firms have the same industry as the delisted firm, which means that matching firms are chosen in the same industry classification in which listed in the IDX.

3. Firms have approximately same size based on the first year of delisted firms sampling. The first year of delisted firms sampling means the size of the delisted companies which is 3 years before it is delisted. The size is compared, firstly, by the market capitalization, as supported by Hackston and Milne (1996), Chan, Covrig, Ng (2004), Huberman and Halka (2005) and from the website of Investopedia. However, some firms don't have approximately the same market capitalization, therefore, the alternative for determining the matching firm size is based on the total assets, which is supported by Titman and Wessels (1988), Barnhart, Marr, and Rosenstein (1994), and Mitton (2002).

\section{Data Collection Method}

First, the financial statements of sample firms in a period of 3 years are downloaded through IDX directory of financial statement. This data collection method is considered as data collection through mechanical observation, because the data is provided in company's record, without researcher being physically present (Sekaran and Bougie, 2010). The essential data which are relevant to the research then extracted from the financial statements into the Microsoft Excel worksheet to be processed later. The data is processed by calculated into the formulas which discussed further in the next section. Finally, after obtaining the desired proxies through formula calculation of data, the data are ready to be analyzed.

\section{Research Variables, Measures, and Model}

This subchapter describes the essentials that act as a basic methodology for the research. Based on the theoretical foundation and review of several literatures above, this segment would selects the proxy used as a measurement of each delisting determinant in this 
thesis. This section will analyzed further about those proxies, which are as follows:

\section{a) Profitability}

Consistent with the research conducted Chaplinsky and Ramchand (2006), this paper uses Return On Assets (ROA) as a measurement of profitability. Return on Assets is computed as net income before noncontrolling interest and nonrecurring items divided by the average total assets of prior year and current year (Gibson, 2011). The ROA term is as follows:

where:

$\mathrm{ROA}_{\mathrm{t}}=$ Return on Assets for the firm in year $t$

$\mathrm{NI}_{\mathrm{t}}=$ Net Incomefor the firm at the end of year $t$ before noncontrolling interest and nonrecurring items

$\mathrm{TA}_{\mathrm{t}}=$ Total Assets for the firm at the end of year $t$

$\mathrm{TA}_{\mathrm{t}-1}=$ Total Assets for the firm at the end of a year before $t$

\section{b) Share's Liquidity}

You, Parhizgari, and Srivastava (2009), through their research of the 355 foreign cross-listing and delisting stocks in 39 countries from 1992 to 2007, examined the changes in price, liquidity and risk in reaction to those cross-listing and delisting. The percentage change in share's trading volume of firm can't be utilized as a measurement for share's liquidity because some of the delisted firms have zero number in trading volume for consecutive years, therefore the data cannot be processed further. Therefore, by adopting Brown, Crocker, Foerster (2007), Lo and Wang (2009), Ibbotson, Chen and Hu (2011), share turnover, which calculated by dividing total trading volume to number of shares outstanding, will be utilized as a measurement for share's liquidity of the firm to measure its effect to delisted firms. The term is as follows:

where:

$\mathrm{ST}_{\mathrm{t}}=$ Shares Turnover of firm for year $t$

$\mathrm{TV}_{\mathrm{t}}=$ Share's trading volume of firm at the end of year $t$

\#shares $=$ Number of shares outstanding of firm at the end of year $t$ 


\section{c) Market Capitalization}

Market capitalization is computed by multiplying number of shares outstanding and the price of the shares. Consistent with a literature review above, the share price is become a vital measurement of market capitalization (Seguin and Smoller, 1997). Moreover, Djama et al. (2012) confirmed that a change in stock price could lead to delisting, which consequently affected to the investors' wealth adversely (Baker and Kennedy, 2002).Therefore, to measure the market capitalization, this thesis utilizes the percentage change in share price of the firm. The term is as follows:

where:

$\% \Delta \mathrm{SP}_{\mathrm{t}}=$ Percentage change in share price of the firm for yeart $\mathrm{SP}_{\mathrm{t}}=$ Share Price of the firmat the end of year $t$

$\mathrm{SP}_{\mathrm{t}-1}=$ Share Priceof the firm at the end of a year before $t$

\section{d) Firm's Leverage}

Leverage is a measure of the degree of protection of long-term funds' supplier (Gibson, 2011). Leverage also known as borrowing capacity ratio. By adopting Marosi and Massoud (2005), as well as Chemla, Pop, and Pop (2008), the leverage of the firm is computed as a ratio of total liabilities to total assets of the firm, which is also known as debt ratio. Therefore, as supported by literatures above, this thesis utilizes Debt Ratio as a measurement/proxy of leverage. The term is as follows:

Where:

$\mathrm{DR}_{\mathrm{t}}=$ Debt ratio of firm for year $t$

$\mathrm{TL}_{\mathrm{t}}=$ Total Liabilities of firm for year $t$

$\mathrm{TA}_{\mathrm{t}}=$ Total Assets of firm for year $t$

\section{e) Firm's Growth Opportunity}

According to Weir et al. (2005) and Thomsen and Vinten (2007), this research apply Tobin's Q ratio as the proxy of firm's growth opportunity. Weir et al. (2005) revealed that the delisted firms had lower growth opportunities as measured by the $\mathrm{Q}$ ratios. Thomsen and 
Vinten (2007) confirmed this idea by stated that Q ratio is higher for firms that remain listed since they have better growth prospects and more expensive to buy. For the firm's growth opportunity, this thesis utilizes Marginal Tobin's Q ratio rather than the actual Tobin's Q ratio due to inflated standard deviation of the data. The marginal Tobin's Q ratio term is as follows:

where:

$\mathrm{Q}_{\mathrm{t}}=$ Tobin's $\mathrm{Q}$ ratio for firm in the year $\mathrm{t}$

$\mathrm{EMV}_{\mathrm{t}}=$ Equity Market Value of a firm at the end of year $t$ (number of shares outstanding multiplied by closing year end share price)

$\mathrm{EBV}_{\mathrm{t}}=$ Equity Book Value of a firm at the end of year $t$

\section{Research Model and Data Analysis Method}

Research

Model

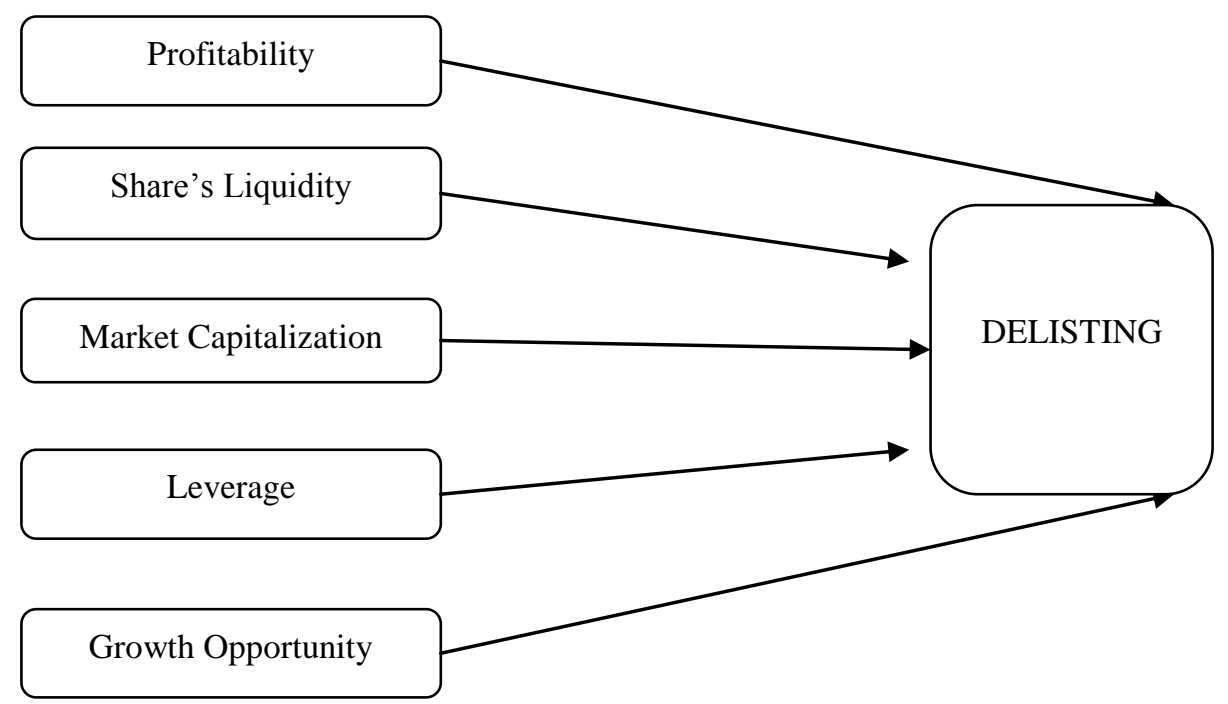

Independent Variables

Dependent Variable

Figure 1. Research Framework

The figure above shows the independent and dependent variables that can be identified in this research. 
This research utilizes logistic regression model, since the dependent variable, in this case which is probability of delisting, is coded 1 for delisted company and 0 for non-delisted company. This is also known as dummy variable (Sekaran and Bougie, 2010; Cooper and Schindler, 2008). DeFusco (2007) stated that logistic regression is a statistical technique used to predict the probability between a dependent variable and a set of independent variable to a logit function logistic curve. The logistic regression model equation of this research is as follows:

where:

Del $_{\text {it }}=$ Delisting probability of firm $i$ at year $t$, which take a value of 1 if the company was delisted, and 0 , otherwise

$\beta_{0}=$ Constant Variable

$\beta_{1}, \beta_{2}, \ldots, \beta_{5}=$ regression coefficients

$\mathrm{ROA}_{\mathrm{it}}=$ Return on Assets ratio of firm $i$ at year $t$

$\mathrm{ST}_{\mathrm{it}}=$ Share's Turnover of firm $i$ at year $t$

$\% \Delta \mathrm{SP}_{\mathrm{it}}=$ Percentage change in share price of firm $i$ at year $t$

$\mathrm{DR}_{\mathrm{it}}=$ Debt ratio of firm $i$ at year $t$

$\mathrm{Q}_{\mathrm{it}}=$ Tobin's q ratio of firm $i$ at year $t$

$\varepsilon_{\mathrm{it}}=$ unobserved error component of firm $i$ at year $t$

\section{FINDINGS AND DISCUSSION}

\section{Final Sample Selection}

As stated in the previous chapter, the sample of this research is selected based on the firms which are delisted from Indonesia Stock Exchange from year 2007 to 2011 and the selected matching companies for each delisted company, which are 31 delisted companies and its matching firms. Unfortunately, due to the insufficient data of variables needed in the research, two companies are ineligible to be included in the research, in which PT Great River International Tbk. (IDX: GRIV) and PT KorporaPersadaInvestamaTbk. (IDX: KOPI). PT Great River International Tbk. (IDX: GRIV) is omitted due to unavailability of financial statements and annual reports for the consecutive 2 sample years, which are in 2005 and 2006. PT KorporaPersadaInvestama also 
share similar issue, in which it is failed to present the financial statements and annual reports for the year 2006.

The rest of 29 delisted companies consist of 16 voluntary delisting (including mergers) and 13 forced delisting. Hence, the final samples of this research are 58 companies, in which 29 delisted firms and a matching firm for each delisted firms, as listed in the Appendix A.

\section{Descriptive Statistics}

This section identifies the analysis on central tendency (measured by minimum, maximum and mean) and the variability (measured by standard deviation) of the observations' distribution through 5 independent variables in 3 years. The analysis itself is grouped among the delisted group and the nondelisted group. The variables are ROA (Return on Assets), ST (Share's Turnover), SP (Percentage change in Share Price), DR (Debt Ratio), and Q (Tobin's Q ratio).

Table 2. Descriptive Statistics of Delisted Firms (Del = 1)

\begin{tabular}{|l|l|r|r|r|r|}
\hline & N & Minimum & Maximum & \multicolumn{1}{c|}{ Mean } & Std. Deviation \\
\hline ROA3 & 29 & -.3560 & .1630 & -.0182 & .1339 \\
ROA2 & 29 & -.2460 & .2510 & -.0077 & .1082 \\
ROA1 & 29 & -.5140 & .3500 & -.0528 & .1965 \\
ST3 & 29 & .0000 & 1.8670 & .1240 & .3516 \\
ST2 & 29 & .0000 & .8440 & .0672 & .1667 \\
ST1 & 29 & .0000 & .7280 & .0677 & .1589 \\
SP3 & 29 & -.8690 & 3.0000 & .1427 & .6902 \\
SP2 & 29 & -.3650 & .9280 & .0763 & .2616 \\
SP1 & 29 & -.4000 & 3.3750 & .1726 & .6375 \\
DR3 & 29 & .1200 & 3.9680 & .8010 & .8249 \\
DR2 & 29 & .0620 & 4.5980 & .8354 & .9079 \\
DR1 & 29 & .0130 & 5.1950 & .9037 & 1.0042 \\
Q3 & 29 & -64.4289 & 21.9688 & .1555 & 13.3447 \\
Q2 & 29 & -23.6221 & 18.6209 & 1.2542 & 6.0607 \\
Q1 & 29 & -10.8086 & 295.7429 & 11.5565 & 54.8871 \\
& & & & & \\
\hline
\end{tabular}

From the statistics above, the average Return on Assets in year t-3 of 29 delisted firms is $1.82 \%$, the average Return on Assets in year t-2 is $-0.77 \%$, and the mean of Return on Assets in year t-1 5.28\%. The statistics do not show a clear trend of decreasing or increasing of ROA pre-delisting. 
Secondly, the average shares turnover in year t-3 of 29 delisted firms is $12.4 \%$. The variability of ST3 is considered high, as the standard deviation of ST3 $(=0.3516)$ is greater than its mean $(0.1240)$. Next, the average turnover of shares in year $\mathrm{t}-2$ is $6.72 \%$. The variability of ST2 is considered medium, as the standard deviation of ST2 $(=0.1667)$ is slightly higher than its mean $(=0.0672)$. Next, the average share's turnover in year t- 1 of 29 delisted firms is $6.77 \%$. The variability of ST1 is considered medium, as the standard deviation of ST1 (=0.1589) is slightly higher than its mean $(=0.0677)$. The delisted sample shows a decreasing trend of share turnover in the market

Thirdly, the average percent change in share price in year t-3 of 29 delisted firms is $14.27 \%$. The variability of SP3 is considered high, as the standard deviation of SP3 $(=0.6902)$ is greater than its mean $(0.1427)$. Next, the average percent change in share price in year $t-2$ is $7.63 \%$. The variability of SP2 is considered high, as the standard deviation of SP2 $(=0.2616)$ is greater than its mean $(=0.0763)$. Next, the average percent change in share price in year $\mathrm{t}-1$ is $17.26 \%$. The variability of SP1 is considered high, as the standard deviation of SP1 $(=0.6375)$ is greater than its mean $(=0.1726)$. Although the turnover of the shares indicated the decreasing trend, the share price changes of the sample trend in the pre-delisting period, do not show a clear trend,

Fourthly, the mean of debt ratio in year t-3 of 29 delisted firms is $80.1 \%$. The variability of DR3 is considered medium, as the standard deviation of DR3 ( $=0.8249)$ is slightly higher than its mean (0.8010). Next, the average debt ratio in year $\mathrm{t}-2$ is $83.54 \%$. The variability of DR2 is considered medium, as the standard deviation of DR2 $(=0.9079)$ is slightly higher than its mean $(=0.8354)$. Next, the average debt ratio in year $\mathrm{t}-1$ of 29 delisted firms is $90.372 \%$. The variability of DR1 is considered medium, as the standard deviation of DR1 $(=1.0042)$ is slightly higher than its mean $(=0.9037)$. The internal factor of delisted sample show a clear increasing debt ratio for the last 3 years preceding the delisted. This indicates on average the delisting companies experienced financial distress prior to delisting.

Lastly, the average Tobin's Q ratio, as a measurement of firm's growth opportunity, in year t-3 of 29 delisted firms is 0.1555 . The variability of Q3 is considered high, as the standard deviation of Q3 
$(=13.3447)$ is greater than its mean (0.1555). Next, the average Tobin's Q ratio in year t-2 is 1.2542. The variability of $\mathrm{Q} 2$ is considered high, as the standard deviation of Q2 $(=6.0607)$ is higher than its mean (=1.2542). Next, the average Tobin's Q ratio in year t-1 of 29 delisted firms is 11.5565 . The variability of Q1 is considered high, as the standard deviation of Q1 $(=54.8871)$ is higher than its mean $(=11.5565)$. The Tobin's Q ratio of delisted sample shows an increasing trend. However, this statistic cannot be interpreted that the sample growth opportunity increases. Since the there is an increasing trend of debt ratio, the increasing Tobin's Q ratio is driven more in the decreasing book value of equity, rather than the market value of equity.

As a comparison, the descriptive statistics of Non-delisted companies (matching companies) are presented below.

Table 3. Descriptive Statistics of Non-Delisted Firms (ProbDel $=0$ )

\begin{tabular}{|l|c|r|r|r|r|}
\hline & N & Minimum & Maximum & Mean & Std. Deviation \\
\hline ROA3 & 29 & -.5450 & .8860 & .0505 & .2081 \\
ROA2 & 29 & -.0760 & .3520 & .0360 & .0745 \\
ROA1 & 29 & -.1770 & .4160 & .0252 & .1037 \\
ST3 & 29 & .0000 & 1.6410 & .3254 & .4576 \\
ST2 & 29 & .0000 & 3.6890 & .5730 & .7947 \\
ST1 & 29 & .0000 & 2.9010 & .4198 & .7018 \\
SP3 & 29 & -.8600 & 2.7270 & .1503 & .6860 \\
SP2 & 29 & -.6940 & 11.9230 & .7936 & 2.2773 \\
SP1 & 29 & -.9440 & 3.3750 & .1662 & 1.0017 \\
DR3 & 29 & .0660 & 1.0880 & .5638 & .2595 \\
DR2 & 29 & .0160 & .8990 & .5227 & .2307 \\
DR1 & 29 & .0170 & .9010 & .5417 & .2378 \\
Q3 & 29 & -2.6444 & 4.6114 & 1.3577 & 1.3398 \\
Q2 & 29 & .3745 & 35.4468 & 2.9744 & 6.4343 \\
Q1 & 28 & .0538 & 65.6893 & 4.0917 & 12.3178 \\
& & & & & \\
\hline
\end{tabular}

After analyze the descriptive statistics of delisted companies, the descriptive of nondelisted companies are as follows. The average Return on Assets in year t-3 of 29 nondelisted firms is $-5.05 \%$. The variability of ROA3 is considered high, as the standard deviation of ROA3 (=0.2081) is greater than its mean $(-0.0182)$. Next, the average 
Return on Assets in year t-2 is $3.60 \%$. The variability of ROA2 is considered medium, as the standard deviation of ROA2 $(=0.0745)$ is slightly higher than its mean $(=0.0360)$. Next, the average Return on Assets in year $\mathrm{t}-1$ is $2.52 \%$. The variability of ROA1 is considered medium, as the standard deviation of ROA1 $(=0.1037)$ is slightly greater than its mean $(=0.0252)$. There is no clear trend of ROA of the matching companies in the last 3 years of delisting period.

Secondly, the average turnover of shares in year t-3 of 29 nondelisted firms is $32.54 \%$. The variability of ST3 is considered medium, as the standard deviation of ST3 $(=0.4576)$ is greater than its mean $(0.3254)$. Next, the average share's turnover in year t-2 is $57.3 \%$. The variability of ST2 is considered medium, as the standard deviation of ST2 $(=0.7947)$ is slightly higher than its mean $(=0.5730)$. Next, the average share turnover in year $\mathrm{t}-1$ is $41.98 \%$. The variability of ST1 is considered medium, as the standard deviation of ST1 $(=0.7018)$ is slightly higher than its mean $(=0.4198)$. Unlike the delisting sample, the matching companies sample does not show the declining of share turnover. However, the average turnover in the last 3 years before the delisting period, the matching companies show a significant higher share turnover compared to the matching companies.

Thirdly, the average percent change in share price in year t-3 of 29 nondelisted firms is $15.03 \%$. The variability of SP3 is considered high, as the standard deviation of SP3 $(=0.6860)$ is greater than its mean (0.1503). Next, the average percent change in share price in year $\mathrm{t}-2$ of 29 nondelisted firms is $79.36 \%$. The variability of SP2 is considered high, as the standard deviation of SP2 $(=2.2773)$ is greater than its mean $(=0.7936)$. Next, the average percent change in share price in year t- 1 of 29 nondelisted firms is $16.62 \%$. The variability of SP1 is considered high, as the standard deviation of SP1 $(=1.0017)$ is greater than its mean $(=0.1662)$.

Fourthly, the average debt ratio in year t-3 of 29 delisted firms is $56.38 \%$. The variability of DR3 is considered low, as the standard deviation of DR3 $(=0.2595)$ is lower than its mean (0.5638). Next the average debt ratio in year $\mathrm{t}-2$ of 29 nondelisted firms is $52.27 \%$. The variability of DR2 is considered low, as the standard deviation of DR2 $(=0.2307)$ is lower than its mean $(=0.5227)$. Next, the average debt ratio in year $\mathrm{t}-1$ of 29 nondelisted firms is $54.17 \%$. The variability of 
DR1 is considered low, as the standard deviation of DR1 $(=0.2378)$ is lower than its mean $(=0.5417)$.

Lastly, for the nondelisted group section, the mean of Q3 is 1.3577. Hence, the average Tobin's Q ratio, as a measurement of firm's growth opportunity, in year t-3 of 29 nondelisted firms is 1.3577 . The variability of Q3 is considered low, as the standard deviation of Q3 $(=1.3398)$ is almost similar to its mean $(=1.3577)$. Next, the average Tobin's Q ratio in year t-2 of 29 nondelisted firms is 2.9744. The variability of Q2 is considered high, as the standard deviation of Q2 $(=6.4343)$ is slightly higher than its mean $(=2.9744)$. Next, the average Tobin's Q ratio in year t-1 of 29 nondelisted firms is 4.0917. The variability of Q1 is considered high, as the standard deviation of $\mathrm{Q} 1(=12.3178)$ is higher than its mean $(=4.0917)$.

\section{Independent Sample T-test}

The two independent samples t-tests are utilized to compare the statistics of two sub- and to test the difference. The results are presented in table below. The analysis is explained after the table below, as follows:

Table 4. Group Statistics - Independent Sample Test

\begin{tabular}{|c|c|c|c|c|c|c|c|c|}
\hline \multirow[b]{2}{*}{ Del } & \multirow[t]{2}{*}{$\mathbf{N}$} & \multirow[t]{2}{*}{ Variable } & \multirow[t]{2}{*}{ Mean } & \multirow[t]{2}{*}{$\begin{array}{c}\text { Std. } \\
\text { Deviation }\end{array}$} & \multirow[t]{2}{*}{ Std. Error Mean } & \multicolumn{3}{|c|}{$\begin{array}{c}\text { t-test for Equality of } \\
\text { Means }\end{array}$} \\
\hline & & & & & & $t$ & df & $\begin{array}{l}\text { Sig (2- } \\
\text { tailed) }\end{array}$ \\
\hline $\begin{array}{l}1 \\
0\end{array}$ & $\begin{array}{l}29 \\
29\end{array}$ & ROA3 & $\begin{array}{r}-.01824 \\
.05048\end{array}$ & $\begin{array}{l}.133865 \\
.208134\end{array}$ & $\begin{array}{l}.024858 \\
.038650\end{array}$ & -1.496 & 47.780 & .141 \\
\hline $\begin{array}{l}1 \\
0\end{array}$ & $\begin{array}{l}29 \\
29\end{array}$ & ROA2 & $\begin{array}{r}-.00772 \\
.03603\end{array}$ & $\begin{array}{l}.108153 \\
.074505\end{array}$ & $\begin{array}{l}.020084 \\
.013835\end{array}$ & -1.794 & 49.690 & .079 \\
\hline $\begin{array}{l}1 \\
0\end{array}$ & $\begin{array}{l}29 \\
29\end{array}$ & ROA1 & $\begin{array}{r}-.05276 \\
.02524\end{array}$ & $\begin{array}{l}.196472 \\
.103686\end{array}$ & $\begin{array}{l}.036484 \\
.019254\end{array}$ & -1.891 & 42.474 & .065 \\
\hline $\begin{array}{l}\mathbf{1} \\
\mathbf{0}\end{array}$ & $\begin{array}{l}29 \\
29\end{array}$ & ST3 & $\begin{array}{l}.12400 \\
.32538\end{array}$ & $\begin{array}{l}.351553 \\
.457627\end{array}$ & $\begin{array}{l}.065282 \\
.084979\end{array}$ & -1.879 & 52.511 & .066 \\
\hline $\begin{array}{l}\mathbf{1} \\
\mathbf{0}\end{array}$ & $\begin{array}{l}29 \\
29\end{array}$ & ST2 & $\begin{array}{l}.06724 \\
.57300\end{array}$ & $\begin{array}{l}.166684 \\
.794695\end{array}$ & $\begin{array}{l}.030952 \\
.147571\end{array}$ & -3.354 & 30.459 & .002 \\
\hline $\begin{array}{l}1 \\
0\end{array}$ & $\begin{array}{l}29 \\
29\end{array}$ & ST1 & $\begin{array}{l}.06772 \\
.41983\end{array}$ & $\begin{array}{l}.158935 \\
.701800\end{array}$ & $\begin{array}{l}.029513 \\
.130321\end{array}$ & -2.635 & 30.865 & .013 \\
\hline
\end{tabular}




\begin{tabular}{|l|l|l|r|r|r|r|r|r|}
\hline $\mathbf{1}$ & 29 & & .14272 & .690225 & .128172 & -.042 & 55.998 & .967 \\
$\mathbf{0}$ & 29 & $\mathbf{S P 3}$ & .15031 & .685964 & .127380 & & & \\
$\mathbf{1}$ & 29 & $\mathbf{S P 2}$ & .07634 & .261599 & .048578 & & & \\
$\mathbf{0}$ & 29 & & .79362 & 2.277312 & .422886 & -1.685 & 28.739 & .103 \\
\hline $\mathbf{1}$ & 29 & $\mathbf{S P 1}$ & .17259 & .637549 & .118390 & & & \\
$\mathbf{0}$ & 29 & & .16621 & 1.001689 & .186009 & .029 & 47.488 & .977 \\
\hline $\mathbf{1}$ & 29 & & .80100 & .824885 & .153177 & & & \\
$\mathbf{0}$ & 29 & $\mathbf{D R 3}$ & .56383 & .259526 & .048193 & 1.477 & 33.489 & .149 \\
\hline $\mathbf{1}$ & 29 & $\mathbf{D R 2}$ & .83538 & .907854 & .168584 & & & \\
$\mathbf{0}$ & 29 & & .52266 & .230721 & .042844 & 1.798 & 31.602 & .082 \\
\hline $\mathbf{1}$ & 29 & $\mathbf{D R 1}$ & .90372 & 1.004200 & .186475 & & & \\
$\mathbf{0}$ & 29 & & .54169 & .237752 & .044150 & 1.889 & 31.129 & .068 \\
\hline $\mathbf{1}$ & 29 & $\mathbf{Q 3}$ & .155498 & 13.3447466 & 2.4780572 & -.483 & 28.564 & .633 \\
$\mathbf{0}$ & 29 & & 1.357682 & 1.3397630 & .2487878 & & \\
\hline $\mathbf{1}$ & 29 & & 1.254249 & 6.0606821 & 1.1254404 & -1.048 & 55.801 & .299 \\
$\mathbf{0}$ & 29 & $\mathbf{Q 2}$ & 2.974362 & 6.4343353 & 1.1948261 & & \\
\hline $\mathbf{1}$ & 29 & $\mathbf{Q 1}$ & 11.556482 & 54.8870580 & 10.1922708 & .725 & 30.719 & .474 \\
$\mathbf{0}$ & 29 & & 3.984757 & 12.1095865 & 2.2486938 & & \\
\hline
\end{tabular}

where: Del $=1$ is the delisted companies sample

$\mathrm{Del}=0$ is the nondelisted companies sample

The table shows there are some factors that significantly differentiate the delisted companies and the non-delisted companies. For the last 2 year before the delisting period, the average ROA of delisted companies are significantly lower than the average ROA of nondelisting companies at $\alpha=10 \%$.

Moreover, for the last 3 years, the delisted firm had significantly lower share turnover than their counterparts (at $\alpha=10 \%$ in year $t-1$ and $5 \%$ in year $\mathrm{t}-2$ and $\mathrm{t}-1)$. This indicates that the investors did not trade the shares of delisted companies as frequent as the matching companies. This could be as a result of the significant different of profitability between the two samples. The other factor is the debt ratio in the last 2 years that is significantly different between the two samples at $\alpha=10 \%$.

\section{Logistic Regression analysis}

This section will discuss further about the summary of the model, which is the R-square coefficient determination, followed by the analysis of the regression result in the next section. 


\section{Model Summary}

This section will present the analysis of how the all elements inside the model (independent variables) describe the prediction/model. The SPSS provides some estimation for R-square coefficient determination. The NagelkerkeR-square is chosen rather than Cox and Snell, because Nagelkerke is the most-reported of the R-squared estimates and a more reliable measure of relationship; more reliable because Nagelkerke modifies the Cox and Snell R-square and has a range from 0 to 1 , which make it easier to interpret (Burns et al., 2008).

Table 5. Models Summary

\begin{tabular}{|c|c|}
\hline Nagelkerke R-Square & Value \\
\hline Model $t$-3 & .198 \\
Model $t$ - 2 & .427 \\
Model $t$ - 1 & .332 \\
\hline
\end{tabular}

In this case, the Nagelkerke R-square for a period $t$ - 3 is 0.198 , which indicates that the predictors/independent variables can be used to describe the dependent variables by $19.8 \%$, while the rest of $80.2 \%$ is outside the scope of the model. For the period of $t$-2, the Nagelkerke $\mathrm{R}$-square is 0.427 , indicating that the independent variables can predict the dependent variables by $42.7 \%$, while $57.3 \%$ is outside the scope of the model. For the period of $t-1$, the Nagelkerke R-square is 0.332 , indicates that $33.2 \%$ of dependent variable's likelihood can be predicted by the independent variables in the model, while $66.8 \%$ is outside the model scope. Based on this result, it can be concluded that the model that provides the best delisting prediction is modelt-2 (2 years before delisting), which then followed by the result of $t-1$ and $t$ 3.

Table 6. Classification Table for model $t-3$

\begin{tabular}{|c|r|r|r|}
\hline \multirow{2}{*}{ Observed } & \multicolumn{3}{|c|}{ Predicted } \\
\cline { 2 - 4 } & \multicolumn{2}{|c|}{ ProbDel } & $\begin{array}{c}\text { Percentage } \\
\text { Correct }\end{array}$ \\
\cline { 2 - 4 } & \multicolumn{1}{|c|}{$\begin{array}{c}\text { 0 } \\
\text { (nondelist) }\end{array}$} & $\begin{array}{c}\text { 1 } \\
\text { (delist) }\end{array}$ \\
\hline \multirow{2}{*}{ ProbDel $\quad$ (nondelist) } & 16 & 13 & 55.2 \\
Overall Percentage & 9 & 20 & 69.0 \\
\hline
\end{tabular}


It can be seen that from the observations for a period of $t-3$, both have 29 sample observation which are Delisted (ProbDel=1) and Nondelisted (ProbDel=0). Among 29 observed non-delisted firms, 13 of them are actually could be delisted based on the observed characteristics of predictors with a cut value of 0.05 . So the percentage correct is $55.2 \%$ between the observed and predicted values of non-delisted company (16 out of 29 is correct). Among 29 delisted firms, 9 of them are actually can be the non-delisted firms, which makes $69 \%$ correct between the observed and predicted value of delisted company. The overall model is $62.1 \%$ accurate.

Table 7. Classification Table for model $t-2$

\begin{tabular}{|c|r|r|r|}
\hline \multirow{2}{*}{ Observed } & \multicolumn{3}{|c|}{ Predicted } \\
\cline { 2 - 4 } & \multicolumn{2}{|c|}{ ProbDel } & $\begin{array}{c}\text { Percentage } \\
\text { Correct }\end{array}$ \\
\cline { 2 - 4 } & \multicolumn{1}{|c|}{$\begin{array}{c}\text { 0 } \\
\text { (nondelist) }\end{array}$} & $\begin{array}{c}\text { 1 } \\
\text { (delist) }\end{array}$ \\
\hline \multirow{2}{*}{ ProbDel 0 (nondelist) } & 18 & 11 & 62.1 \\
1 (delist) & 3 & 26 & 89.7 \\
Overall Percentage & & & 75.9 \\
\hline
\end{tabular}

Next, for the period $t-2$, among 29 observed non-delisted firms, 11 of them are actually could be delisted based on the observed characteristics of predictors with a cut value of 0.05 . So the percentage correct is $62.1 \%$ between the observed and predicted values of non-delisted company (18 out of 29 is correct). Among 29 delisted firms, 3 of them are actually can be the non-delisted firms, which makes $89.7 \%$ correct between the observed and predicted value of delisted company. The overall model is $75.9 \%$ accurate.

Table 8. Classification Table for model $t-1$

\begin{tabular}{|c|c|c|c|c|}
\hline \multirow{3}{*}{\multicolumn{2}{|c|}{ Observed }} & \multicolumn{3}{|c|}{ Predicted } \\
\hline & & \multicolumn{2}{|c|}{ ProbDel } & \multirow{2}{*}{$\begin{array}{c}\text { Percentage } \\
\text { Correct }\end{array}$} \\
\hline & & \begin{tabular}{|c}
$\mathbf{0}$ \\
(nondelist)
\end{tabular} & $\begin{array}{c}1 \\
\text { (delist }\end{array}$ & \\
\hline ProbDel & 0 (nondelist) & 17 & 1 & 58.6 \\
\hline
\end{tabular}


Finally, for the period $t-1$, among 29 observed non-delisted firms, 12 of them are actually could be delisted based on the observed characteristics of predictors with a cut value of 0.05 . So the percentage correct is $58.6 \%$ between the observed and predicted values of non-delisted company (17 out of 29 is correct). Among 29 delisted firms, 6 of them are actually can be the non-delisted firms, which makes $79.3 \%$ correct between the observed and predicted value of delisted company. The overall model is $69.0 \%$ accurate.

Hence, based on classification matrix of the model for each year, again it suggests that the model is more accurate at a period $t-2$ with $75.9 \%$ accuracy, followed by result of period $t-1$ (69\% accuracy) and $t-2$ (62.1\% accuracy).To conclude this section, in terms of accuracy of the model, a model with the most accuracy based on the logistic regression result will be selected from every sample $(t-3, t-2, t-1)$. From the Model Summary, the Nagelkerke R-square for a period $t-3$, $t-2, t-1$ respectively are $0.198,0.427$ and 0.332 . From the Classification Table, the overall predicted percentage correct for $t-3, t$ $2, t-1$ respectively are $62.1 \%, 75.9 \%$, and $69.0 \%$. Hence, based on the highest result in Model Summary and Classification Table results, it can be concluded that the model which provides the best delisting prediction is model $t-2$, which is a period of 2 years prior to delisting (Nagelkerke R-square $=.427$, Classification Table Predicted $75.9 \%$ accuracy).

\section{Hypothesis Result Analysis}

This section will provide analysis of the outcomes of the logistic regression result for each determinant for every sample year prior to delisting.

The logistic regression results for each year are presented and will be discussed separately, as follows:

Table 9. Logistic Regression Result for Model $t-3$

\begin{tabular}{|r|r|r|r|r|r|}
\hline & \multicolumn{1}{|c|}{ B } & \multicolumn{1}{c|}{ S.E. } & Wald & \multicolumn{1}{c|}{ Sig. } & Exp (B) \\
\hline ROA3 & -2.778 & 2.072 & 1.798 & .180 & .062 \\
ST3 & -1.805 & .915 & 3.896 & .048 & .164 \\
SP3 & .521 & .498 & 1.094 & .296 & 1.683 \\
DR3 & .709 & .675 & 1.103 & .294 & 2.032
\end{tabular}




\begin{tabular}{|r|r|r|l|l|l|}
$\mathbf{Q 3}$ & -.008 & .033 & .057 & .811 & .992 \\
Constant & -.100 & .538 & .035 & .852 & .904 \\
\hline
\end{tabular}

Table 10. Logistic Regression Result for Model $t-2$

\begin{tabular}{|r|r|r|r|r|r|}
\hline & \multicolumn{1}{|c|}{ B } & \multicolumn{1}{|c|}{ S.E. } & \multicolumn{1}{c|}{ Wald } & \multicolumn{1}{c|}{ Sig. } & Exp (B) \\
\hline ROA2 & -3.208 & 4.177 & .590 & .442 & .040 \\
ST2 & -4.272 & 1.667 & 6.566 & .010 & .014 \\
SP2 & -.203 & .767 & .070 & .791 & .816 \\
DR2 & .597 & .763 & .612 & .434 & 1.816 \\
Q2 & -.028 & .070 & .156 & .693 & .973 \\
Constant & .590 & .622 & .899 & .343 & 1.804 \\
\hline
\end{tabular}

Table 11. Logistic Regression Result for Model $t-1$

\begin{tabular}{|r|r|r|r|r|r|}
\hline & \multicolumn{1}{|c|}{ B } & \multicolumn{1}{|c|}{ S.E. } & \multicolumn{1}{c|}{ Wald } & \multicolumn{1}{c|}{ Sig. } & Exp (B) \\
\hline ROA1 & -1.971 & 2.225 & .785 & .376 & .139 \\
ST1 & -4.057 & 1.938 & 4.383 & .036 & .017 \\
SP1 & .980 & .565 & 3.013 & .083 & 2.666 \\
DR1 & .496 & .634 & .612 & .434 & 1.642 \\
Q1 & .002 & .010 & .057 & .811 & 1.002 \\
Constant & .125 & .550 & .051 & .821 & 1.133 \\
\hline
\end{tabular}

\section{Profitability}

The first hypothesis is:

$\mathrm{Ha}_{1}$ : Profitability of the firm decreases delisting probability

From the table above, ROA3 has p-value of .180 and Wald value of 1.798. This result shows an insignificant effect between Return on Asset in a period of 3 years before delisting ( $t-3)$ and the probability of delisting, although the result suggests a negative $\mathrm{B}$ coefficient of 2.778 , which means that profitability of a firm decreases the delisting probability for period t-3. These results suggest that in period t-3, even though there is no significant effect of Return on Asset to the probability of delisting, profitability of a firm is proved to decreases the delisting probability. But as it has no significant effect, therefore first hypothesis is rejected in period $\mathrm{t}-3$.

The ROA2 has p-value of .442 and Wald of .590, which again shows that there is no significant effect between Return on Asset in a period of 2 years before delisting ( $\mathrm{t}-2)$ and the probability of delisting, although the result suggests a negative B coefficient of -3.208 , which 
means that profitability of a firm decreases the delisting probability for period $\mathrm{t}-2$. It can be derived from the results above that in period $\mathrm{t}$ 2 , profitability of a firm decreases the delisting probability, but as its effect is not significant, the first hypothesis is rejected for period $t-2$.

ROA1 also have a similar result as ROA2 and ROA3, in which it has no significant effect of Return on Asset in a period of 1 year before delisting ( $\mathrm{t}-1)$ to the probability of delisting, although the result suggests a negative $\mathrm{B}$ coefficient of -1.971 , which means that profitability of a firm decreases the delisting probability for period t -1 . The result for period t- 1 again shows no significant effect between profitability (ROA1) and the probability of delisting, although it shows that profitability decreases the delisting probability; first hypothesis is rejected for period $\mathrm{t}-1$.

There is inadequate evidence that prior yearsprofitability of a firm decreases the probability of delisting. Although this result have stated the same negative coefficient as stated by Chaplinsky and Ramchand (2008) in their findings, it still contradicts to their research, which stated that profitability is one of important (significant) determinants for delisting probability in the U.S. market for the period 1961-2004; while in this research profitability is found insignificantly related to the delisting probability. This could be suggested that profitability is not a significant determinant of company delisting in Indonesia or the insignificancy is due to small sample size and low time constraint, comparing to Chaplinsky's research.

\section{Shares Liquidity}

The second hypothesis is:

$\mathrm{Ha}_{2}$ : Shares liquidity of the firm decreases delisting probability

From the table above, ST3 has p-value of .048 ( $\mathrm{p}<0.05$ significance level) and Wald value of 3.896. This result shows that there is a significant effect between share's turnover in a period of 3 years before delisting (t-3) and the probability of delisting, with a negative value of $\mathrm{B}$, which is -1.805 . This means that share's turnover (share's liquidity) of a firm decreases the delisting probability for period $\mathrm{t}-3$.

Next, ST2 has a significant level of .010 and Wald of 6.566, which shows that there is a significant effect between turnover of shares for 
a period of 2 years before delisting ( $\mathrm{t}-2)$ and the probability of delisting, with a negative $\mathrm{B}$ value of -4.272 .

Similar result also shown in ST1 (share's turnover for year t-1), where the $\mathrm{p}$-value is below 0.05 significance level $(\mathrm{p}=.036, \mathrm{p}<0.05)$ and has 4.383 value of Wald, which also considered to have a significant effect towards the probability of delisting ( $\mathrm{B}=-4.057)$. The negative value of B for share's turnover coefficients of all years suggests that share's liquidity decreases the probability of delisting, and since the pvalue is considered significantly affected the model, therefore it can be concluded that the second hypothesis is accepted for all sample periods.

This result agrees with research done by Chandy, Sarkar, Tripathy (2004), as well as You, Parhizgari and Srivastava (2009), which found that share's liquidity decreases delisting probability and proved that liquidity is statistically significant to the probability of delisting. Furthermore, You et al. (2009) also stated that delisting is followed by decreased liquidity, and it is seem persistent over the long run.

\section{Market Capitalization}

The third hypothesis is:

$\mathrm{Ha}_{3}$ : Market capitalization of the firm decreases delisting probability From the table above, SP3 (changes in share price in a period of 3 years before delisting) has p-value of .296 and Wald value of 1.094, which is considered to have an insignificant effect towards the probability of delisting. The $\mathrm{B}$ coefficient is positive $(\mathrm{B}=.521)$, which means that changes in share price at $\mathrm{t}-3$ increases the delisting probability. As it is insignificant and yet increases the delisting probability, therefore the third hypothesis is rejected for the period t3.

The SP2 has p-value of .791 and Wald of .070, which shows that there is no significant effect between changes in share price in a period of 2 years before delisting $(\mathrm{t}-2)$ and the probability of delisting. The result of $\mathrm{B}(\mathrm{B}=-.203)$ suggests that changes in share price in period $\mathrm{t}-2$ decrease the delisting probability, but as there is no significant effect to the probability of delisting, based on the p-value, the third hypothesis is rejected for period $\mathrm{t}-2$.

Next, $p$-value of SP1 which is below 0.1 level of significance $(p=.083$, $\mathrm{p}<.01$ ) with a Wald value of 3.013, suggests that the result has a slight 
significant and has a positive $\mathrm{B}(\mathrm{B}=.980)$. But, seeing from this result, the third hypothesis is rejected for period $\mathrm{t}-3$ since the result of market capitalization increase the delisting probability.

The results of the effect of market capitalization, which both increasing and decreasing the probability of delisting, are found insignificant. The result of market cap causes a decrease in delisting probability is supported by Seguin and Smoller (1997), as well as Kim and Lyn (1991), due to strategic reasons; the management may decide to go private when they found the share price is undervalued, or else they are willing to extract private benefits and to avoid opportunity costs of staying listed. But the result in Indonesia shows that the share price as the proxy of market cap is not significant to determine the probability of delisting. Furthermore, the market cap as an enhancement in delisting probability is outside the scope of this research.

\section{Leverage}

The fourth hypothesis is:

\section{$\mathrm{Ha}_{4}$ : Firm's leverage increases delisting probability}

From the table above, DR3 has p-value of .294 and Wald value of 1.103. This result shows an insignificant effect between debt ratio (leverage) in a period of 3 years before delisting ( $t-3)$ and the probability of delisting, although the result suggests a positive B coefficient of .709, which means that leverage of a firm increases the delisting probability for period $\mathrm{t}-3$.

The DR2 has p-value of .434 and Wald of .612, which again shows that there is no significant effect between leverage in a period of 2 years before delisting $(\mathrm{t}-2)$ and the probability of delisting, although the result suggests a positive B coefficient of .597, which means that a firm's leverage increases the probability of delisting for period t-2.

DR1 presents a similar result as DR2 and DR3, in which it has no significant effect $(p>0.05)$ of leverage in a period of 1 year before delisting ( $\mathrm{t}-1)$ to the probability of delisting, although the result suggests a positive B coefficient of .496 , which means that leverage increases the delisting probability for period $t-1$. These results conclude that even though leverage is proved to increases the 
probability of delisting, there is no significant effect of leverage to the probability of delisting, therefore fourth hypothesis is rejected for every sample year.Chen et al. (2010) also found a positive relationship of leverage and delisting probability as higher leverage would increase default risk, leading to more delistings; which also supported by Marosi and Massoud (2005), through their research of a sample of 406 deregistering firms in the SEC's EDGAR database for January 1996-May 2004 period, found that a 1\% increases in leverage increases the probability of delisting increase by $31 \%$. But the results from this research stated that leverage is not a significant factor that drives to the delisting in Indonesia.

\section{Firm's Growth Opportunity}

The last hypothesis is:

$\mathrm{Ha}_{5}$ : Firm's Growth Opportunity decreases delisting probability

From the table above, Q3 (Tobin's Q ratio in a period of 3 years before delisting) has p-value of .811 and Wald value of .057, which is considered to have an insignificant effect towards the probability of delisting. The $\mathrm{B}$ coefficient is negative $(\mathrm{B}=-0.008)$, which means that firm's growth opportunity at $\mathrm{t}-3$ decreases the delisting probability, but as the p-value is insignificant, the fifth hypothesis is rejected for period $\mathrm{t}-3$.

The Q2 has p-value of .693 and Wald of .156, which shows that there is no significant effect between firm's growth opportunity in a period of 2 years before delisting ( $\mathrm{t}-2)$ and the probability of delisting. The result of $\mathrm{B}(\mathrm{B}=-.028)$ suggests that firm's growth opportunity in period t-2 decrease the delisting probability, but again as its effect is insignificant to the probability of delisting, the hypothesis is rejected for period $\mathrm{t}-2$.

Next, with p-value of .811 for Q1 and Wald value of .057, suggests that the result has no significant effect to the model. The Q1 has a diminutive positive value of $\mathrm{B}(\mathrm{B}=.002)$, which means that firm's growth opportunity in $\mathrm{t}-1$ almost have no effect to the delisting probability, therefore the hypothesis is rejected for the period $\mathrm{t}-1$.

Prior studies by Weir et al. (2005), Li, Zhang and Zou (2006) and Leuz et al. (2008) discovered that one controlling variables that related significantly to delisting rates of IPOs is the growth of the firms (measured by Q ratio); the higher the growth of the firms' value 
the higher the probability for the firms to survive after IPO. In other words, the lower the growth of the firm the higher probability for the firms to got delisted. The result from this research in Indonesia stated differently. It suggests that firm's growth opportunity is not a significant factor that triggered the delisting. Moreover, it stated an increasing effect of the probability, which is outside the research scope.

In conclusion, the significant determinant factor that affects the probability of delisting in Indonesia, which supports prior researches and literatures, is share's liquidity of a firm. Share's liquidity significantly decreases the probability of delisting in Indonesia. Two determinants (Profitability and Leverage), which effects are correctly predicted in the hypothesis development in the previous Chapter 2, seems to be insignificantly affect to the delisting probability. In this research, profitability appears to insignificantly decrease the delisting probability, while leverage appears to insignificantly increase the delisting probability; this insignificancy issue could be due to small sample size. The other two determinants, which are market capitalization and growth opportunity seems to be both insignificant and unpredictable because of their effect of increasing and decreasing the probability of delisting

\section{CONCLUSION AND RECOMMENDATION}

\section{Conclusion}

Delisting is one of the most impacting issues of corporate finance segment which affecting the listed company in regional stock exchange market. The delisting phenomenon is quite a new issue in Indonesia, therefore not much research is found regarding delisting phenomenon in Indonesia. This research is aimed to investigate further about the determinant factors which caused the delisting phenomenon in Indonesia Stock Exchange and to give a prediction for future issue regarding delisting of company.

From the findings it can be concluded that there is one significant factor that consistently affecting delisting probability for the last 3 years prior to the delisting, which is shares liquidity of a firm.

Meanwhile profitability, market capitalization, leverage and growth opportunity appear to be insignificant towards the delisting probability. Some determinants although their effects on the 
probability of delisting are found to be statistically insignificant, the results show that those determinants interact with the probability of delisting as expected; those determinants are profitability and leverage. In this research, profitability seems to decrease the probability of delisting insignificantly, while leverage seems to increase the probability of delisting insignificantly.

Based on the research findings, the delisting could be predictable as far as 3 years before the firm will be delisted $(t-3)$, however the most accurate period to predict the delisting is 2 years before the firm will be delisted $(\mathrm{t}-2)$.

To conclude this research, if it seen thoroughly, the determinant factors of company delisting can be divided into two major parts, which are internal factors (elements which come from the company within itself that affect the businesses, in this case, such as profitability, leverage, market capitalization and growth opportunity) and external factors (elements that affect businesses which come from outside of the company, such as customer, or in this case, share's liquidity which is moved by the market). Based on this idea, the delisting phenomenon in Indonesia is more affected by the external factors rather than the internal factors of the company.

In conducting this research, some limitations have been encountered, which are as follows:

1. Sample Size

Since the delisting phenomenon is a new issue in Indonesia, a sample of 29 delisted firms and its matching firms for a 5-year period may not represent the delisting phenomenon in Indonesia Stock Exchange Market fully. The insignificancy of the variables/determinants may also cause by the lack of sample size.

2. Limited Source of Research Model

As the prior researches and studies about delisting are not much, the author, based on own determination from limited source review, has selectedthe determinants which is considered to affect the delisting phenomenon in Indonesia.

3. Determination of Matching Firms Selection

The matching firms are chosen based on the matching firm criteria stated in chapter 3, but not all of the delisted firms have the exact matching firms, meaning the matching firms chosen are far from the matching firm criteria, due to limited firms on certain industry. 


\section{Recommendations}

Some recommendations to related entities are developed, regarding this research, which are as follows:

1. IDX should improve its database, in terms of completeness, efficiency and time constraints. Investors, both local and foreign investors, will be relying on IDX to access important historical data from Indonesia Stock Exchange Market. It is inefficient for the investors if IDX can't provide such information, as it is the center of Indonesia Financial Market.

2. For future research, it is recommended to improve the sample size. Larger sample size tends to have better and more reliable statistical result. Widening the time frame of the research could be the way to enhance the sample size.

3. To enhance the accuracy of a research regarding delisting determinant factors, this thesis could be utilized as a reference. The next researcher may use different variables or more advanced proxies and determinants for further studies.

\section{REFERENCES}

Angel, J., Harris, J., Panchapagesan, V., \& Werner, I. (2004). From pink slips to pink sheets: market quality around delisting from NASDAQ. Retrieved March 23, 2012, from www.simon.rochester.edu/fac/zhang/papers/delisting05Ap25r. pdf.

Baker, G., \& Kennedy, R. (2002). Survivorship and the economic grim reaper. The Journal of Law, Economics, and Organization, 18(2), 324-361.

Baker, H., \& Edelman, R. (1992). The Effects on Spread and Volume of Switching to the NASDAQ National Market System. Financial Analysts' Journal, 48: 83-86.

Barnhart, S., Marr, M., \& Rosenstein, S. (1994). Firm performance and board composition: Some new evidence. Managerial and Decision Economics, 15(4), 329-340, DOI: 10.1002/mde.4090150407. 
Bharath, S., \& Dittmar, A. (2010). Why do firms use private equity to opt out of public markets? Review of Financial Studies, 23, 1771-1818.

Black, H. C. (1990). Black's Law Dictionary. West Publishing Co.: Minnesota.

Brown, J., Crocker, D., \& Foerster, S. (2007). Liquidity and Investment Styles. Northfield Annual Research Conference (p. 13). Richard Ivey School Of Business: The University of Western Ontario.

Burns, R. B., Burns, R., \& Burns, R. P. (2008). Business Research Methods and Statistics Using SPSS. London: SAGE Publications Ltd.

Chan, K., Covrig, V., \& Ng, L. (2005). What Determines the Domestic Bias and Foreign Bias? Evidence from Mutual Fund Equity Allocations Worldwide. The Journal Of Finance, 60(3), 1495-1534, DOI: 10.1111/j.1540-6261.2005.768_1.x.

Chandy, P. R., Sarkar, S. K., \& Tripathy, N. (2004). Empirical Evidence on the Effects of Delisting from National Market System. Journal of Economics and Finance, 28(1), 46-55. Retrieved March 20, 2012 from http://search.proquest.com/docview/215575710?accountid=31 532.

Chaplinsky, S., \& Ramchand, L. (2006). From Listing to Delisting: Foreign Firms' Entry and Exit from the U.S. Charlottesville: University of Virginia.

Chemla, G., Pop, A., \& Pop, D. (2008, August). Delisting decisions in frontier emerging markets: An institutional profile of going to private transactions in Romania. Retrieved March 29, 2012, from Yale School of Management: Millstein Center for Corporate Governance and Performance web site: http://millstein.som.yale.edu/sites/millstein.som.yale.edu/files/ Pop_Diana.pdf

Chen, J., Rutherford, R., \& Wang, P. (2010). The Competing-risk Analysis of post-IPO Delistings.

Cooper, D. R., \& Schindler, P. S. (2008). Business Research Methods 10th ed. New York: McGraw-Hill. 
Craig, M. (2011). Staging Connections Group Limited (ASX: STG): ASX Announcement: Minimum Holding Buyback and Proposed Delisting. Rozelle: Staging Connections Group Limited.

Das, S., Saudagaran, S. M., \& Sinha, R. (2004). An Empirical Examination of NYSE Stocks Voluntarily De-listing from the Tokyo Stock Exchange. Review of Accounting and Finance, 3(4), 47-72.

DeAngelo, H., DeAngelo, L., \& Skinner, D. (1996). Reversal of Fortune: Dividend Signaling and the Disappearance of Sustained Earnings Growth. Journal of Financial Economics, 40, 341-372.

DeFusco, R., McLeavey, D., Pinto, J., \& Runkle, D. (2007). Quantitative Investment Analysis 2nd ed. New Jersey: John Wiley \& Sons, Ltd.

Djama, C., Martinez, I., \& Serve, S. (2011, January 17). What do We Know about Delistings? A Survey of Literature. Retrieved March 5, 2012, from SSRN: http://papers.ssrn.com/sol3/papers.cfm?abstract_id=1968352.

Delisting and Relisting of Securities at the Exchange, Kep308/BEJ/07-2004 (Decision of Board of Directors of the Jakarta Stock Exchange Inc. July 19, 2004).

Edelman, R., \& Baker, H. (May 1990). Liquidity and Stock Exchange Listing. Financial Review, 25(2), 231-249 doi: 10.1111/j.1540-6288.1990.tb00794.x.

Edelman, R., \& Baker, H. (Oct. 1987). The Effects of Delisting on the Price Behavior of Common Stocks. Working Paper, American Univ.

Fama, E. F., \& French, K. R. (2004). New lists: fundamentals and survival rates. The Journal of Financial Economics, 73, 229269.

Gibson, C. H. (2011). Financial Statement Analysis. Canada: SouthWestern, Cengage Learning.

Hackston, D., \& Milne, M. (1996). Some determinants of social and environmental disclosures in New Zealand companies. 
Accounting, Auditing \& Accountability Journal, 9(1), 77-108, doi: 10.1108/09513579610109987.

Hansen, B., Pownall,, G., \& Wang, X. (2009). The robustness of the Sarbanes Oxley effect on the U.S. capital market. Review of Accounting Studies, doi:10.1007/s11142-009-9094-7.

Harris, T. S. (2009). Discussion of "The robustness of the Sabarnes Oxley effect on the U.S. capital market'. Rev Account Stud 14, 440-452, DOI 10.1007/s11142-009-9099-2.

Healy, P., \& Palepu, K. (1990). Effectiveness of Accounting-Based Dividend Covenants. Journal of Accounting and Economics, $12,97-124$.

Hernawan, B. W., \& Tirtayatra, I. B. (2005, October). Go Private. Retrieved February 27, 2012, from Bapepam Web site: http://www.bapepam.go.id/old/layanan/warta/2005_oktober/G o Private.pdf

Huberman, G., \& Halka, D. (2001). Systematic Liquidity. Journal of Financial Research, 24(2), 161-178.

Ibbotson, R., Chen, Z., \& Hu, W. (April 21, 2011). Liquidity as an Investment Style. Retrieved May 4, 2012 from SSRN website: http://ssrn.com/abstract=1817889 or http://dx.doi.org/10.2139/ssrn.1817889.

Kim, W., \& Lyn, E. (1991). Going private: corporate restructuring under information asymmetry and agency problems. Journal of Business Finance \& Accounting 18, 637-648.

Leuz, C., Triantis, A., \& Wang Tracy. (2004, November). Why Do Firms Go Dark? Causes and Economic Consequences of Voluntary SEC Deregistrations. Retrieved March 18, 2012, from fic.wharton.upenn.edu/fic/papers/04/0419.pdf

Leuz, C., Triantis, A., \& Wang, T. (181-208). Why do firms go dark? Causes and economic consequences of voluntary SEC deregistrations. Journal of Accounting \& Economics, 45, 2008.

Li, J., Zhang, L., \& Zhou, J. (2006, March 20). Earnings Management and Delisting Risk of Initial Public Offerings. Retrieved March 20, 2012, from Simon School, University of Rochester website: 
http://www.simon.rochester.edu/fac/zhang/delistingMarch20.p df

Lo, A., \& Wang, J. (2009). Stock Market Trading Volume. THE HANDBOOK OF FINANCIAL ECONOMETRICS, Retrieved from SSRN website: http://ssrn.com/abstract=1405583.

Loon, L., \& De Ramos, A. (January 2009). Related-Party Transactions: Cautionary Tales for Investors in Asia. RelatedParty Transactions: Cautionary Tales for Investors in Asia, 141, doi: 10.2469/ccb.v2009.n1.1.

Loon, L., \& Pica, A. (2010). Independent Non-Executive Directors: A Search for True Independence in Asia. 1-49, doi: 10.2469/ccb.v2010.n1.1.

Macey, J., O'Hara, M., \& Pompilio, D. (2003). Down and Out in the Stock Market: The Law and Economics of the Delisting Process. Johnson Graduated School of Management, Cornell University.

Mantysaari, P. (2009). The Law of Corporate Finance: General Principles and EU Law Volume III: Funding, Exit, Takeovers. Heidelberg: Springer.

Market Capitalization. (n.d.). Retrieved May 4, 2012, from Investopedia:

http://www.investopedia.com/terms/m/marketcapitalization.as p\#axzz1uLqKOboE

Marosi, A., \& Massoud, N. (2004, November). Why Do Firms Go Dark? Retrieved March 18, 2012, from SSRN: http://papers.ssrn.com/sol3/papers.cfm?abstract_id=570421

Mehran, H., \& Peristiani, S. (2009). Financial visibility and the decision to go private. Review of Financial Studies 23, 519547.

Mitton, T. (2002). A cross-firm analysis of the impact of corporate governance on the East Asian financial crisis. Journal of Financial Economics, 64(2), 215-241, doi: 10.1016/S0304405X(02)00076-4. 
Palepu, K. (1987). An anatomy of an Accounting Change. In: Bruns Jr., W., Kaplan, R. (Eds.). Accounting and Management: Field Study Perspectives. HBS Press, Boston MA.

Pamungkas, R. A. (2011, September 8). IDX May Delist 11 Stocks. Retrieved March 12, 2012, from Indonesia Finance Today Web site:

http://en.indonesiafinancetoday.com/read/10298/IDX-MayDelist-11-Stocks

Pamungkas, R. A. (2011, June 22). Panca Wiratama May Be Forced to Delist. Retrieved March 12, 2012, from Indonesia Finance Today Web site:

http://en.indonesiafinancetoday.com/read/6930/Panca-

Wiratama-May-Be-Forced-to-Delist

Pamungkas, R. A. (2011, February 10). Stock Market to Consider Delisting Illiquid Stocks. Retrieved March 12, 2012, from Indonesia Finance Today Web site: http://en.indonesiafinancetoday.com/read/2054/Stock-Marketto-Consider-Delisting-Illiquid-Stocks-

Pamungkas, R. A., \& Teguh, A. (2011, April 28). Non-Liquid Stocks Delisting. Retrieved March 12, 2012, from Indonesia Finance Today Web site: http://en.indonesiafinancetoday.com/read/4853/Non-LiquidStocks-Delisting

Pamungkas, R. A., Darmawan, A. D., \& Rowena. (2011, May 2). Alfa Retailindo to Delist. Retrieved March 12, 2012, from Indonesia Finance Today Web site: http://en.indonesiafinancetoday.com/read/4926/AlfaRetailindo-to-Delist

Pamungkas, R. A., Darmawan, A. D., \& Rowena. (2011, May 2). Alfa Retailindo to Delist. Retrieved March 12, 2012, from Indonesia Finance Today Web site: http://en.indonesiafinancetoday.com/read/4926/AlfaRetailindo-to-Delist

Parker, C. L. (October 2004). “GOING PRIVATE”: BUSINESS AND PROCEDURAL CONSIDERATIONS IN SEEKING RELIEF FROM REPORTING AND CORPORATE GOVERNANCE REQUIREMENTS. California: Rutan \& Tucker, LLP. 
Permatasari, R. I. (2011, December 30). 2011, Rekor Terbanyak Emiten Delisting. Retrieved February 27, 2012, from Seputar Indonesia web site: http://www.sindonews.com/read/2011/12/30/278/549617/2011 -rekor-terbanyak-emiten-delisting\#

Public Company Considerations for Going Private. (2012). Retrieved February 23, 2012, from Mercer Capital web site: http://www.mercercapital.com/print/?id=320

Sanger, G. C., \& Peterson, J. D. (1990, June). An Empirical Analysis of Common Stock Delistings. Journal of Financial and Quantitative Analysis, 25(2), pp. 261-272.

Seguin, P., \& Smoller, M. (1997). Share price and mortality: an empirical evaluation of newly listed Nasdaq stocks. Journal of Financial Economics 45, 333-363.

Sekaran, U., \& Bougie, R. (2010). Research Methods for Business: A Skill Building Approach, 5th ed. United States: John Wiley \& Sons, Ltd.

Siddaiah, T. (2011). Financial Services. Noida: Dorling Kindersley (India) Pvt. Ltd.

Thomsen, S., \& Vinten, F. (2007, April 3). Delistings in Europe and the Costs of Governance. Retrieved March 25, 2012, from SSRN:

http://papers.ssrn.com/sol3/papers.cfm?abstract_id=986603

Titman, S., \& Wessels, R. (Mar., 1988). The Determinants of Capital Structure Choice. The Journal of Finance, 43(1), 1-19.

Weir, C., Laing, D., \& Wright, M. (2005). Undervaluation, private information, agency costs and the decision to go private. Applied Financial Economics, 15, 947-961.

Widjaja, G., \& Risnamanitis, W. (2009). Go Public dan Go Private di Indonesia. Jakarta: Prenada Media Group.

You, L., Parhizgari, A., \& Srivastava, S. C. (2009, March 9). Cross Listing and Subsequent Delisting in Foreign Markets. Retrieved March 18, 2012, from SSRN: http://papers.ssrn.com/sol3/papers.cfm?abstract_id=1356201. 